\title{
Model Pembelajaran SQ3R Berbantuan Buku Cerita Meningkatkan Keterampilan Membaca Siswa
}

\author{
I Wayan Misnawan ${ }^{1}$, Desak Putu Parmiti², Ndara Tanggu Renda ${ }^{3}$ iD \\ ${ }^{1,2,3}$ Prodi Pendidikan Guru Sekolah Dasar, Universitas Pendidikan Ganesha, Singaraja, Indonesia \\ *Corresponding author: misnawanarimbawa@gmail.com
}

\begin{abstract}
Pembelajaran membaca yang dilakukan pada proses pembelajaran, rata-rata siswa kurang mampu melakukan pelafalan dengan baik dan masih belum memahami bahan bacaan. Salah satu cara untuk mengatasi hal tersebut yaitu, penerapan model SQ3R berbantuan buku cerita. Penelitian ini bertujuan untuk mengetahui pengaruh yang signifikan model pembelajaran $S Q 3 R$ berbatuan Buku Cerita terhadap Keterampilan Membaca pada Siswa SD kelas III. Jenis penelitian ini adalah penelitian eksperimen semu dengan rancangan Non-Equivalent posttest only control group design. Populasi pada penelitian ini berjumlah 248 siswa. Sedangkan sampel pada penelitian ini berjumlah 48 siswa dengan teknik menggunakan teknik random sampling. Data kompetensi pengetahuan dikumpulkan dengan menggunakan metode non tes dengan menggunakan instrumen lembar observasi. Data yang diperoleh dianalisis menggunakan analisis statistik inferensial (t-test). Berdasarkan hasil analisis data diperoleh rata-rata keterampilan membaca di kelas eksperimen 80 dan di kelas kontrol 65 , sedangkan thitung diperoleh nilai signifikansi 2 arah (2-tailed) sebesar $0,000<0,05$ sehingga $\mathrm{H}_{0}$ ditolak atau $\mathrm{H}_{1}$ diterima. Dengan demikian, dapat diinterpretasikan bahwa model pembelajaran SQ3R Berbatuan Buku Cerita berpengaruh positif terhadap Keterampilan Membaca Pada Siswa SD kelas III. Implikasi pada penelitian ini adalah dengan menarapkan model pembelajaran SQ3R berbantuan buku cerita mengakibatkan siswa bertambah gairah sehingga keterampilan membca siswa meningkat.
\end{abstract}

Keywords: Keterampilan Membaca, SQ3R, Buku Cerita

\begin{abstract}
Learning to read is done in the learning process, on average students are less able to pronounce it well and still do not understand the reading material. One way to overcome this is by applying a story book-assisted SQ3R model. This study aims to obtain information on whether there is a significant effect of the SQ3R Rocky Story Book learning model on reading skills in third grade elementary school students. This type of research is a quasi-experimental study with a Non-Equivalent posttest only control group design. The population in this study amounted to 248 students. While the sample in this study amounted to 48 students with techniques using random sampling techniques. Knowledge competency data was collected using a non-test method using an observation sheet instrument. The data obtained were analyzed using inferential statistical analysis (t-test). Based on the results of data analysis, the average reading skills in the experimental class 80 and in the control class 65, while tcount obtained 2-tailed significance value of 0,000 <0.05 so that HO is rejected or H1 is accepted. Thus, it can be interpreted that the SQ3R Rocky Story Book learning model has a positive effect on Reading Skills in Grade III Elementary Students. The implication of this research is to expect the SQ3R learning model aided by story books to result in students becoming more aroused so that their reading skills increase.
\end{abstract}

Keywords: Reading Skills, SQ3R, Story Books

$\begin{array}{lll}\text { History: } & & \text { Publisher: Undiksha Press } \\ \text { Received } & : 16 \text { Mei } 2020 & \text { Licensed: This work is licensed under } \\ \text { Revised } & : 1 \text { Juni } 2020 & \text { a Creative Commons Attribution 3.0 License } \\ \text { Accepted } & : \text { 12 Juli } 2020 & \text { SA }\end{array}$




\section{Introduction}

Bahasa Indonesia merupakan salah satu mata pelajaran yang dibelajarkan di SD. Menurut Aryani, dkk (2012) bahasa Indonesia merupakan mata pelajaran yang penting dalam kurikulum pendidikan dasar. Humaira, dkk (2012) menjelaskan, Bahasa Indonesia adalah salah satu mata pelajaran membaca, menulis, mengarang, berbicara atau menceritakan sesuatu. Sedangkan Hidayah, dkk (2014)menyatakan hakitat pembelajaran bahasa adalah belajar berkomunikasi serta belajar mengungkapkan maksud sesuai dengan konteks lingkungan. Lebih lanjut, Susanto (2013) menyatakan bahwa Bahasa Indonesia merupakan suatu alat yang penting dalam rangka merealisasikan dalam mencapai tujuan kebahasaan Indonesia yang dipelajari oleh semua siswa dari sekolah dasar hingga sekolah menengah atas bahkan di perguruan tinggi. Selanjutnya, Dibia \& Dewantara (2012) bahasa adalah alat komunikasi yang memungkinkan terjadinya komunikasi dua arah.

Bahasa Indonesia sebagai mata pelajaran memiliki beberapa standar keterampilan yang harus dikuasi oleh siswa, salah satunya adalah keterampilan membaca. Keterampilan membaca merupakan keterampilan dasar yang harus dikuasai oleh siswa sekolah dasar, karena keterampilan ini akan terus digunakan ketika melanjutkan ke jenjang pendidikan yang lebih tinggi. Menurut Pramesti (2015) keterampilan membaca adalah kemampuan untuk memahami suatu teks dan tidak hanya melafalkan tulisan, tetapi juga melibatkan aktivitas visual dan berpikir. Selanjutnya, Arini, dkk (2017) menyatakan membaca merupakan suatu proses yang bersifat fisik dan psikologis, dimana proses yang bersifat fisik berupa kegiatan mengamati tulisan secara visual dengan indera visual ini pembaca mampu mengenali dan membedakan gambar-gambar bunyi serta kombinasinya. Melalui proses recoding, pembaca mengasosiasikan gambar-gambar bunyi beserta kombinasinya itu dengan bunyi-bunyian. Sedangkan proses psikologis berupa kegiatan berpikir dalam mengolah informasi. Melalui proses decoding, gambar-gambar bunyi dan kombinasinya diidentifikasi, diuraikan kemudian diberi makna. Menurut Dibia (2018) tujuan membaca yaitu: (1) kesenangan, (2) menyempurnakan membaca nyaring, (3) menggunakan strategi tertentu, (4) memperbaharui informasi yang telah diketahui, (5) memperoleh informasi untuk laporan lisan tertulis, (6) mengkonfirmasikan atau menolak prediksi, (7) menampilkan suatu eksperimen atau mengaplikasikan informasi yang diperoleh dari suatu teks dalam beberapa cara lain dan mempelajari tentang struktur teks, (8) menjawab pertanyaan-pertanyaan yang spesifik.

Ada beberapa aspek hal yang harus diperhatikan dalam keterampilan membaca, Barbeang Abbot dan Dawson (dalam Dalman, 2013) aspek keterampilan membaca yaitu: (1) kelas I meliputi keterampilan mempergunakan ucapan yang tepat; mempergunakan frasa yang tepat; menggunakan intonasi suara sederhana agar makna mudah dipahami; menguasai tanda-tanda baca seperti titik (.), koma (,), tanda tanya (?), dan tanda seru (!), (2) kelas II meliputi keterampilan membaca dengan terang dan jelas; membaca dengan penuh perasaan, ekspresi; membaca tanpa terbata-bata, (3) kelas III meliputi keterampilan membaca dengan penuh perasaan, ekspresi; mengerti serta memahami bahan bacaan, (4) kelas IV meliputi memahami bahan bacaan pada tingkat dasar; kecepatan mata dan suara, (5) kelas V meliputi keterampilan membaca dengan pemahaman dan perasaan; kecepatan membaca nyaring bergantung pada bahan bacaan; dapat membaca tanpa terus-menerus melihat pada bahan bacaan, (6) kelas VI meliputi keterampilan membaca nyaring dengan penuh perasaan atau ekspresi; membaca dengan penuh kepercayaan dan menggunakan susunan kata yang tepat.

Namun kenyataannya keterampilan membaca siswa tergolong masih rendah. Hasil studi PISA 2018 yang dirilis oleh OECD menunjukkan bahwa kemampuan siswa Indonesia dalam membaca, meraih skor rata-rata yakni 371, dengan rata-rata skor OECD yakni 487 (Mendikbud, 2019). Selain itu, studi dokumen terhadap nilai UTS Bahasa Indonesia yang dilaksanakan pada kelas III SD di Gugus V Kecamatan Sukasada Kabupaten Buleleng Tahun Pelajaran 2019/2020 menunjukan dari total 248 siswa, ternyata masih terdapat $186(75 \%)$ 
siswa yang belum mencapai KKM. Data tersebut mengindikasikan terdapat masalah terhadap keterampilan membaca siswa. Melalui observasi ditemukan beberpa fakta yang berkaitan dengan keterapilan membaca siswa, yaitu: (1) pada saat pembelajaran membaca, rata-rata siswa kurang mampu melakukan pelafalan dengan baik dan masih belum memahami bahan bacaan, (2) cara membaca siswa masih terbata-bata, (3) pada saat membaca siswa cenderung kurang memperhatikan tanda baca, (4) guru kurang menggunakan media dan alat peraga pada saat pelaksanaan pembelajaran, (5) kurangnya model pembelajaran yang digunakan oleh guru dalam kegiatan pembelajaran. Hal tersebut juga dikuatkan oleh pernyataan guru-guru saat diwawancara. Guru menjeslakan ada beberapa kendala yang sering dihadapi guru dalam proses pembelajaran yaitu: (1) kurangnya perhatian siswa terhadap materi yang dijelaskan oleh guru sehingga pembelajaran menjadi pasif, (2) waktu yang digunakan tidak cukup untuk menyampaikan materi pembelajaran yang padat, sehingga memperlambat penyelesaian materi pembelajaran, (3) kurangnya media pembelajaran yang disediakan oleh pihak sekolah sehingga pada saat pembelajaran guru jarang menggunakan media.

Merujuk pada permasalah di atas, perlu dilaksanakan pembelajaran yang dapat mengoptimalkan keterampilan membaca siswa, sehingga akan berdampak pada peningkatan hasil belajar siswa. Salah satunya dengan menggunakan model pembelajaran SQ3R, karena model pembelajaran SQ3R menuntun siswa untuk membaca secara aktif dan memahami isi bacaan dengan baik. Menurut Effendi (2016) model pembelajaran SQ3R adalah model pembelajaran yang dirancang untuk membantu siswa memahami materi pelajaran dengan tahapan-tahapan survey, question, read, recite, dan review. Sedangkan menurut Huda (2014) SQ3R merupakan strategi pemahaman yang membantu siswa berpikir tentang teks yang sedang mereka baca. Sering kali dikategorikan sebagai strategi belajar, SQ3R membantu siswa 'mendapatkan sesuatu' ketika pertama kali membaca teks. Bagi guru, SQ3R membantu mereka dalam membimbing siswa bagaimana membaca dan berpikir layaknya para pembaca efektif. Dalam kegiatan model pembelajaran SQ3R ini kegiatan membaca merupakan proses menyeimbangkan antara teks yang dibaca dengan pengetahuan yang dimiliki siswa, sehingga siswa dapat memahami makna-makna yang terkadang dalam bacaan ketika membaca. Nurhayati (2018) menyatakan bahwa SQ3R merupakan suatu teknik pembelajaran membaca pemahaman yang dipercaya membuat siswa bisa dengan mudah belajar dan memahami bahan bacaan yang dibaca. Hasanah, dkk (2013) SQ3R merupakan model pembelajaran yang memiliki sintaks terarah yang hampir sama dengan langkah metode ilmiah.

Slamet (2014) langkah-langkah penerapan metode SQ3R (Survey, Question, Read, Recite, dan Review) sebagai berikut; a). Guru bersama siswa melakukan survey (5 hingga 10 menit). Sebelum membaca, siswa diarahkan melihat secara keseluruhan bahan bacaan dengan membaca judul, subjudul, atau struktur teksnya dan ulangi proses ini bila yang dibaca berupa buku; b). Siswa dengan dipandu guru merumuskan pertanyaan (5 hingga 10 menit). Pertanyaan yang dirumuskan dikaitkan dengan kata kunci dan ulangi proses ini hingga muncul pertanyaan-pertanyaan sejumlah kata kunci yang diidentifikasi sebelumnya; c). Siswa membaca secara mandiri dengan cara lebih lambat dari kegiatan membaca sebelumnya (waktu disesuaikan dengan kualitas dan kuantitas teks) dan penuh konsentrasi dengan memberi perhatian yang lebih banyak pada bagian yang relevan dengan rumusan pertanyaan; d). Siswa diminta menyatakan (tanpa bersuara) atau menuliskan isi yang dibaca dengan menjawab pertanyaan yang telah dirumuskan dengan kata-kata sendiri dan ulangi proses ini pada tugas berikutnya bila yang dibaca berupa buku; dan e). Siswa meninjau ulang bagianbagian yang perlu diperdalam atau mengecek kebenaran jawaban atas pertanyaan yang dirumuskan sebelum membaca (5 menit). Menurut hasil penelitian Rahmawati (2016) pengimplementasian model SQ3R berbantuan Reka Cerita Gambar dapat meningkatkan hasil belajar dan pemahaman membaca siswa. Selanjutnya, hasil penelitian Artu (2016) dan Agustina \& Hariyadi (2018) menunjukan terjadi peningkatan kecakapan membaca individu 
seiring diterapkannya model pembelajaran SQ3R. Lebih lanjut, hasil penelitian Afriyeni, dkk (2017) menunjukan, model pembeljaran SQ3R efektif meningkatkan kemampuan pemahaman konsep dan prosedural matematika siswa.

Proses pembelajaran menggunakan model SQ3R akan lebih efektif jika dibantu dengan buku cerita. Menurut Faizah (2009) buku cerita adalah sebuah cerita yang ditulis dengan gaya bahasa ringan, cenderung dengan gaya obrolan, dilengkapi dengan gambar yang merupakan kesatuan dari cerita untuk menyampaikan fakta atau gagasan tertentu. Pendapat lain tentang buku cerita bergambar juga diungkapkan oleh Rothlein dan Meinbach (dalam Adipta, dkk 2016) "a picture story books conveys its message through illustrations and written text; both elements are equally important to the story". Ungkapan ini mengandung pengertian bahwa cerita bergambar adalah buku yang memuat pesan melalui ilustrasi yang berupa gambar dan tulisan. Gambar dan tulisan tersebut membentuk kesatuan yang utuh. Menurut Arnasih, dkk (2015) buku cerita memiliki berbagai maaf dalam pembelajaran khususnya di kelas rendah yang meliputi: meningkatkan gairah peserta didik untuk belajar, memberikan teladan, dan hiburan. Senada dengan pendangan tersebut, Asriyani, dkk (2017) juga menyatakan untuk meningkatkan keterampilan membaca peserta didik diperlukan sumber bacaan yang menarik contontonya seperti cerita rakyat yang disesuaikan dengan umur siswa. Selanjutnya Davis (dalam Adipta, 2016) menyatakan alasan cerita bergambar dijadikan sebagai sebagai bahan bacaan adalah: (a) mendorong semangat belajar; (b) mudah didapatkan di koran dan toko buku; (c) berisi cerita tentang kehidupan sehari-hari; dan (d) memberikan gaya belajar yang bervariasi.

Secara garis besar buku cerita bergambar merupakan cerita yang ditulis dengan gaya bahasa ringan yang dilengkapi dengan gambar yang menjadi satu kesatuan serta memuat pesan yang terkandung dalam setiap gambar secara utuh. Buku cerita ini sangat cocok jika dikombinasikan dengan model pembelajaran SQ3R di dalam proses pembelajaran di kelas, karena dapat menambah semangat dan motivasi siswa untuk belajar terutama belajar membaca. Dengan menggunakan media buku cerita akan merangsang siswa untuk aktif dan semangat dalam belajar, sehingga dapat meningkatkan keterampilan siswa dalam membaca. Menurut hasil penetian Prayoga, dkk (2017) menunjukan penerapan progam literasi berbantuan buku cerita anak dapat meningkatkan keterampilan menulis cerita narasi siswa sekolah dasar. Selanjutnya, hasil penelitian Nurfitriana \& Heryatun (2018) menyatakan terjadi peningkatan hasil belajar membaca pemahaman bahasa Indonesia dengan diterapkannya pendekatan Contextual Teaching and Learning berbantuan media buku cerita bergambar. Lebih lanjut, hasil penelitian Arnasih, dkk (2015) juga menunjukan implementasi pembelajaran tematik berbantuan cerita berpengaruh positif terhadap aktivitas belajar dan prestasi belajar calistung siswa.

Penelitian ini bertujuan untuk mengetahui pengaruh model pembelajaran SQ3R berbantuan buku cerita terhadap keterampilan membaca pada siswa sd kelas III. Perbedaan penelitian ini dengan penelitian sejenis, yaitu pengimplementasian model pembelajaran SQ3R dipadukan dengan buku cerita terhadap keterampilan membaca siswa.

\section{Materials and Methods}

Penelitian ini merupakan eksperimen semu (Quasi Eksperimen). Karena tidak semua variabel yang muncul dan kondisi eksperimen dapat diatur dan dikontrol secara ketat. Penelitian ini menggunakan rancangan non-equivalent post-test only control grup design. Populasi pada penelitian ini adalah seluruh kelas III SDN di Gugus V Kecamatan Sukasada yang berjumlah 248 siswa. Gugus V Kecamatan Sukasada terdiri dari 8 SD. Sebelum pengambilan sampel langkah pertama yang harus dilakukan adalah menguji kesetaraan. Uji kesetaraan ini menggunakan analisis Anava satu jalur berbantuan aplikasi Microsoft Excel. Berdasarkan uji hipotesis dan tabel ringkasan ANAVA satu jalur, dapat disimpulkan bahwa 
$F_{\text {hitung }}<\mathrm{F}_{\text {tabel }}(1,58<2,28)$ dengan taraf signifikansi $5 \%$ ini berarti $\mathrm{H}_{0}$ diterima dan $\mathrm{H}_{1}$ ditolak, dengan demikian kemampuan siswa SD kelas III di Gugus V Kecamatan Sukasada adalah setara. Setelah diketahui populasi pada penelitian ini setara maka, langkah selanjutnya yaitu menentukan sampel penelitian. Untuk pengambilan sampel pada penelitian ini digunakan teknik random sampling. Hasil pengundian menunjukkan SDN 3 Panji sebagai kelas eksperimen dan SDN 5 Panji sebagai kelas kontrol.

Metode yang digunakan pada penelitian ini adalah metode non tes atau dengan melakukan observasi. Jenis instrumen yang digunakan dalam penelitian ini adalah non tes yaitu observasi keterampilan membaca siswa pada pelajaran Bahasa Indonesia. Pada penelitian ini instrumen yang digunakan adalah lembar observasi. Penyusunan lembar observasi keterampilan membaca siswa pada penelitian ini menggunakan kisi-kisi yaitu: 1) Keterampilan Membaca, 2) Penguasaan tanda baca sederhana, 3) Kejelasan ucapan, 4) Kelancaran membaca (tanpa terbata-bata), dan 5) Memahami bahan bacaan.

Sebelum Instrumen penelitian ini digunakan terlebih dahulu dilakukan penilaian pakar (jugges) sebelum instrumen digunakan. Selanjutnya instrumen tersebut dianalisis dengan menggunakan uji validitas dan reliabilitas. Hasil uji validitas isi menurut Gregory yang didapat pada penelitian ini adalah 0,44 dan berada pada kategori sedang. Sedangkan hasil reliabilitas di dapatkan skor 0,647 , ini berarti instrumen dinyatakan reliable. Analisis statistik deskriptif yang digunakan yaitu, skor rata-rata (mean) tiap-tiap variabel di konversikan dengan menggunakan kriteria rata-rata ideal (Mi) dan standar deviasi ideal (SDi), serta untuk menentukan skala penilaian lima. Sedangkan uji prasyarat yang harus dipenuhi sebelum melakukan analisis data utama untuk menguji hipotesis penelitian yaitu uji normalitas sebaran data ditiap kelompok dan uji homogentitas varians antar kelompok. Uji hipotesis yang digunakan adahah uji-t.

\section{Results and Discussion}

Tujuan pada penelitian ini, untuk mengetahui perbedaan model pembelajaran SQ3R berbantuan buku cerita pada siswa kelas eksperimen dengan model pembelajaran non SQ3R berbantuan buku cerita pada siswa kelas kontrol. Analisis data penelitian ini adalah analisis statistic deskriptif dan analisis statistic inferensial. Adapun rangkuman hasil analisis statistik deskriptif dan inferensial disajikan pada Tabel 1.

Tabel 1 . Hasil Analisis Statistik Deskriptif dan Inferensial

\begin{tabular}{ccc}
\hline Variabel & Kelas Kontrol & Kelas Eksperimen \\
\hline Jumlah Siswa & 22 & 26 \\
\hline Mean & 65,00 & 80,00 \\
\hline Median & 65,00 & 80,00 \\
\hline Range & 40 & 30 \\
\hline Standar Deviasi & 10,351 & 9,798 \\
\hline Varians & 107,143 & 96,000 \\
\hline Uji Normalitas & 0,200 dan 0,783 & \\
\hline Uji Homogenitas & 0,657 & \\
\hline Uji-t & 0,000 & \\
\hline
\end{tabular}

Berdasarkan Tabel 1 hasil analisis deskriptif diperoleh skor rata-rata keterampilan membaca kelas eksperimen yaitu 80.00 dengan kategori sangat tinggi sedangkan skor ratarata keterampilan membaca kelas kontrol yaitu 65.00 dengan kategori tinggi. Besar standar deviasi kelompok eksperimen adalah 9,789 dengan varians 96,00, sedangkan besar standar deviasi pada kelas kontrol sebesar 10,351 dengan varians 107,143.

Setelah dilakukan analisis deskriptif data, dilanjutkan dengan uji normalitas data. Uji normalitas menggunakan teknik statistik Kolmogorov-Smirnov dan Shapiro-Wilk dianalisis 
dengan bantuan SPSS 16.0 for Windows. Untuk analisis menggunakan Kolmogorov-Smirnov diperoleh sig untuk kelas eksperimen dan kelas kontrol masing-masing 0,100 dan 0,200. Hasil ini menunjukkan bahwa skor sig lebih besar dari pada 0,05 sehingga $\mathrm{H}_{0}$ diterima, sedangkan analisis menggunakan Shapiro-Wilk diperoleh sig untuk kelas eksperimen dan kelas kontrol masing-masing sebesar 0,063 dan 0,783. Hasil ini menunjukkan bahwa skor sig lebih besar dari pada 0,05 sehingga $\mathrm{H}_{0}$ diterima. Sehingga dapat disimpulkan bahwa data skor post-tes kelas eksperimen dan kelas kontrol berdistribusi normal.

Hasil uji homogenitas digunakan metode Levene's Test dianalisis dengan bantuan SPSS 16.0 for Windows. Untuk metode Levene's Test diperoleh sig 0,657> 0,05 dengan demikian dapat disimpulkan hasil data skor post-tes siswa bersifat homogen. Hasil uji-t diperoleh nilai signifikansi 2 arah (2-tailed) $0,000<0,05$ sehingga terdapat perbedaan skor yang berarti antara kelompok kelas kontrol dan eksperimen. Sehingga $\mathrm{H}_{0}$ ditolak dan $\mathrm{H}_{1}$ diterima.

Berdasarkan rata-rata keterampilan membaca, hasil penelitian ini menunjukkan bahwa terdapat perbedaan signifikan model pembelajaran SQ3R berbantuan Buku Cerita pada siswa kelompok eksperimen dan model pembelajaran non SQ3R berbantuan Buku Cerita pada siswa kelompok kontrol, setelah kelompok diberikan perlakuan sebanyak 8 kali, selanjutnya kedua kelompok tersebut diberikan post-tes untuk mengukur keterampilan membaca. Adapun hasil analisis data penelitian pada kedua kelompok diperoleh rerata keterampilan membaca siswa pada kelas eksperimen adalah 80 dan pada kelas kontrol adalah 65. Selanjutnya data keterampilan membaca Bahasa Indonesia siswa tersebut diuji dengan menggunakan statistik uji-t dan diperoleh hasil nilai signifikansi 2 arah (2-tailed) $0,000<0,05$. Hal ini berarti hipotesis alternatif yang menyatakan bahwa ada pengaruh yang signifikan model pembelajaran SQ3R berbantuan Buku Cerita dibandingkan dengan kelompok siswa yang dibelajarkan dengan model pembelajaran non SQ3R berbantuan Buku Cerita dengan taraf signifikansi $5 \%$ diterima.

Hasil keterampilan membaca siswa pada kelas eksperimen lebih baik apabila dibandingkan dengan hasil keterampilan membaca siswa pada kelas kontrol, hal tersebut disebabkan oleh perbedaan langkah-langkah pembelajaran antara kelas eksperimen dan kontrol. Kelas eksperimen dibelajarkan menggunakan model SQ3R berbantuan buku cerita yang terdiri dari 5 tahapan. Menurut Ngalimun (dalam Afriyeni, dkk 2017) tahap pertama adalah survey, pada tahap ini siswa mementuk kelompok kemduan mensurvey buku cerita yang diberian oleh guru. Pada tahap ini kecermatan siswa akan terlatih karena siswa akan secara mandiri mencermati materi dalam pembelajaran. Tahap kedua Question, yaitu siswa dapat membuat pertanyaan (mengapa-bagaimana-darimana) tentang materi pelajaran bahasa indonesia yang dibacanya. Disini siswa didorong aktif menemukan pertanyaan yang tentunya materi yang belum dipahami. Tahap ketiga Read, yaitu dengan membaca materi pelajaran bahasa indonesia dan cari jawaban yang dari permasalahan atau pertanyaan yang sudah ditemukan. Pada tahap ini siswa akan terlatih untuk secara cermat dan terampil mengumpulkan informasi untuk menjawab pertanyaan atau masalah yang dihadapinya. Tahap keempat Recite, yaitu mempertimbangkan jawaban yang sudah didapat, pada tahap ini siswa akan dilatih untuk mengambil keputusan secara tepat dengan mempertimbangkan segala kemungkinan yang ada terkait jawaban yang ia dapat. Tahap kelima Review, yaitu meninjau ulang kebenaran dari jawaban yang diperoleh. Pada tahap ini akan memperdalam pengetahuan siswa karena siswa meninjau ulang bagian-bagian yang perlu di perdalam serta mengecek kebenaran jawaban atas pertanyaan yang telah dirumuskan.

Penggunaan model SQ3R pada penelitian ini sejalan dengan beberapa hasil peneltian yaitu penelitian oleh Putri, dkk (2014) yang menyatakan bahwa terdapat perbedaan yang signifikan hasil belajar yang signifikan antara kelompok siswa yang mengikuti pembelajaran dengan model pembelajaran SQ3R dengan kelompok siswa yang mengikuti pembelajaran 
konvensional. Kelompok siswa eksperimen memperoleh hasil belajar yang leih tinggi. Selanjutnya hasil penelitian oleh Putri (2019) yang menyatakan terdapat perbedaan keterampilan membaca yang signifikan antara siswa yang dibelajarkan menggunakan model pembelajaran SQ3R dan siswa yang dibelajarkan dengan model pembelajaran konvensional, dimana keterampilan membaca siswa kelompok eksperimen lebih baik.

Selain karena perbedaan langkah-langkah model pembelajaran SQ3R juga diterapkan dengan berbantuan Buku Cerita sehingga dapat menambah minat siswa untuk belajar dan menciptakan pembelajaran yang aktif dan menyenangkan. Hal tersebut dikarenakan pesanpesan dan materi pembelajaran dikemas dengan menarik menggunakan buku cerita bergambar, gambar dan tulisan tersebut membentuk kesatuan yang utuh (Rothlein dan Meinbach (dalam Adipta, 2016) Penggunaan buku cerita bergambar pada penelitian ini sejalan dengan hasil penelitian oleh Marantika (2019) yang menyatakan terdapat pengaruh yang positif pada penggunaan media pembelajaran buku cerita bergambar terhadap keterampilan membaca nyaring peserta didik kelas III di MIN 7 Bandar Lampung. Selanjutnya oleh Mawaddah (2018) yang menyatakan bahwa buku cerita bergambar memberikan pengaruh yang baik terhadap kemampuan membaca pemahaman siswa Kelas III MI Mimbarul Huda Langkap Tahun Pelajaran 2017/2018.

Ada beberapa keunggulan model pembelajaran SQ3R berbantuan Buku Cerita yaitu: 1) siswa diarahkan untuk berpikir kreatif terhadap bahan bacaan yang diberikan sehingga mampu membuat pertanyaan-pertanyaan yang kreatif, 2) siswa berusaha untuk memikirkan jawaban dari pertanyaan-pertanyaan yang diperoleh, 3) siswa dapat bekerjasama dalam kelompoknya untuk saling bertukar pikiran dan pendapat serta memahami materi yang disajikan. Menurut Masykur, dkk (2006) keunggulan model pembelajaran SQ3R yaitu siswa dapat lebih berkonsentrasi serta memahami isi materi dengan lebih baik. Hal ini sejalan dengan beberapa hasil penelitian yang dilakukan sebelumnya, yang mengungkapkan bahwa model pembelajaran SQ3R berbantuan Buku Cerita efektif digunakan dalam pembelajaran, salah satunya yaitu penelitian yang dilakukan oleh Rahmawati (2016) terdapat perbedaan yang signifikan antara siswa yang dibelajarkan menggunakan model pembelajaran SQ3R berbantuan reka cerita gambar dan siswa yang dibelajarkan dengan model pembelajaran non SQ3R berbantuan reka cerita gambar.

Berbeda halnya dengan belajar menggunakan model pembelajaran non SQ3R berbantuan Buku Cerita yang dilakukan guru pada kelas kontrol. Selama proses pembelajaran guru bertindak sebagai pelaksana proses pembelajaran. Umumnya yang dilakukan oleh guru hanya ceramah, mendemonstrasikan suatu hal, dan mendiskusikan apa yang telah dilihat atau didengar. Sehingga guru menjadi lebih aktif dibandingkan siswa, karena aktivitas siswa lebih banyak duduk, mendengarkan, mencatat, dan menghafal. Pembelajaran seperti itu membuat siswa bosan, cepat mengantuk, tidak fokus terhadap pembelajaran, dan saling ganggu serta bercanda antar siswa. Hal tersebut keterampilan membaca siswa yang dibelajarkan dengan menggunakan model non SQ3R berbantuan Buku Cerita lebih rendah dibandingkan siswa yang dibelajarkan dengan menggunakan model pembelajaran SQ3R berbantuan Buku Cerita. Tinjauan ini didasarkan pada perbedaan nilai rerata keterampilan membaca antara kelompok eksperimen dan kelompok kontrol. Berdasarkan pemaparan di atas, dapat disimpulkan bahwa penerapan model pembelajaran SQ3R berbantuan Buku Cerita berpengaruh positif terhadap keterampilan membaca pada siswa kelas III di SD Gugus V Kecamatan Sukasada tahun pelajaran 2019/2020. Perbedaan penelitian ini dengan penelitian yang sejenisnya terletak pada penggunaan model pembelajaran SQ3R berbantuan Buku Cerita.

Perbedaan penelitian ini dengan penelitian sebelum-sebelumnya adalah pada penerapan model pembelajaran SQ3R di dukung oleh penggunaan buku cerita bergambar, sehingga pembelajaran dapat berjalan dengan lebih optimal. Hal tersebut terjadi karena pembelajaran yang dikemas kedalam bentuk cerita bergambar akan lebih menarik perhatian 
siswa sehingga siswa menjadi lebih nyaman dan senang dalam belajar. Hal tersebut didukung oleh pendapat Rothlein dan Meinbach (dalam Adipta, 2016) yang menyatakan siswa akan lebih mudah paham dan tidak mudah bosan apabila pesan-pesan dan materi pembelajaran dikemas dengan menarik menggunakan buku cerita bergambar, gambar dan tulisan tersebut membentuk kesatuan yang utuh. Implikasi pada penelitian ini adalah dengan menerapkan model pembelajaran SQ3R berbantuan buku cerita mengakibatkan siswa bertambah gairah sehingga keterampilan membaca siswa meningkat.

\section{Conclusion}

Berdasarkan hasil penelitian dan pembahasan yang telah dipaparkan, dapat disimpulkan bahwa terdapat pengaruh yang signifikan model pembelajaran SQ3R berbantuan Buku Cerita terhadap keterampilan membaca pada siswa kelas III di SDN Gugus V Kecamatan Sukasada Tahun Pelajaran 2019/2020. Dengan demikian model pembelajaran SQ3R berbantuan Buku Cerita berpengaruh terhadap keterampilan membaca siswa. Saran yang dapat disampaikan berdasarkan penelitian yang telah dilakukan yaitu kepada seluruh siswa kelas III di SDN Gugus V Kecamatan Sukasada agar selalu giat belajar, memperhatikan pembelajaran dengan baik, serta berpartisipasi aktif dalam proses pembelajaran sehingga dapat mencapai keterampilan membaca yang optimal khususnya pada mata pelajaran Bahasa Indonesia. Sedangkan untuk guru dengan diterapkannya model pembelajaran SQ3R pada penelitian ini, hendaknya guru lebih termotivasi dalam menggunakan model-model pembelajaran yang inovatif dalam melaksanakan proses pembelajaran di kelas yang dapat meningkatkan kualitas proses dan keterampilan membaca siswa, sehingga tujuan pembelajaran yang diharapkan tercapai secara optimal. Untuk kepala sekolah agar dapat menjadikan hasil penelitian ini sebagai dasar pengambilan kebijakan untuk membimbing guru dalam mengembangkan model-model pembelajaran yang inovatif. Sedangkan untuk peneliti lain yang berminat untuk mengadakan penelitian lebih lanjut tentang model pembelajaran SQ3R dapat menggunakan hasil penelitian ini sebagai acuan ke perpustakaan untuk melakukan penelitian dalam variabel yang sama ataupun pada variabel yang berbeda

\section{References}

Adipta, H., Maryaeni, M., \& Hasanah, M. (2016). Pemanfaatan Buku Cerita Bergambar Sebagai Sumber Bacaan Siswa SD. Jurnal Pendidikan, 1(5).

Afriyeni, S., Haji, S., \& Connie. (2017). No Title. Jurnal Pendidikan Matematika Raflesia, 2(1).

Agustina, R., \& Hariyadi, H. (2018). No Title. AKSIS: Jurnal Pendidikan Bahasa Dan Sastra Indonesia, 2(1), 69-80.

Arini, Kristiantari, Rini, M. G., \& Ganing, N. N. (2017). Pendidikan Bahasa dan Sastra Indonesia di Kelas Rendah. Undiksha.

Arnasih, N. W., Marhaeni, M. P. A. N., \& Putu, M. S. P. I. B. (2015). Pengaruh Implementasi Pembelajaran Tematik Berbantuan Cerita Terhadap Aktivitas dan Prestasi Belajar Calistung Siswa Kelas III SD di Gugus V Kecamatan Tegallalang Kabupaten Gianyar (Doctoral dissertation, Ganesha University of Education).

Artu, N. (2016). Upaya Meningkatkan Kemampuan Membaca Pemahaman Siswa Kelas IV SDN Pembina Liang Melalui Penerapan Strategi Survey Questions Reading Recite Review (SQ3R). Jurnal Kreatif Online, 2(2). 
Aryani, S., Samadhy, U., \& Sismulyasih, N. (2012). Keterampilan Membaca Pemahaman Melalui Strategi Know-Want-Learned (KWL) pada Siswa Kelas IVA SDN Sekaran 01 Semarang. Joyful Learning Journal, 1(1).

Asriyani, N. K. S., Rati, N. W., \& I Nyoman Murda. (2017). Pengaruh Model Pembelajaran Cooperative Script Berbantuan Cerita Rakyat Terhadap Literasi Siswa Kelas III SD. Mimbar PGSD Undiksha, 5(2).

Dalman. (2013). Keterampilan Membaca. PT Raja Grafindo Persada.

Dibia, \& Dewantara. (2012). Bahasa Indonesia dalam Karya Ilmiah. Singaraja. Universitas Pendidikan Ganesha.

Dibia, I. K. (2018). Apresiasi Bahasa dan Sastra Indonesia. PT Raja Grafindo Persada.

Effendi, R. (2016). Model Pembelajaran SQ3R Untuk Mengembangkan Kemampuan Literasi Siswa. Kalamatika: Jurnal Pendidikan Matematika, 1(2).

Faizah, U. (2009). Keefektifan cerita bergambar untuk pendidikan nilai dan keterampilan berbahasa dalam pembelajaran Bahasa Indonesia. Jurnal Cakrawala Pendidikan, 3(3).

Hasanah, M., Abdullah, A., \& Sugianto, S. (2013). Pengaruh Model Pembelajaran Survey, Question, Read, Recite, Review (Sq3r) dan Learning Strategy Terhadap Kesadaran Metakognisi dan Hasil Belajar Kognitif Pada Materi Pengaruh Kepadatan Populasi Manusia Terhadap Lingkungan. Jurnal Biologi Edukasi, 5(2).

Hidayah, N. (2014). Pendekatan Pembelajaran Bahasa Whole Language. TERAMPIL: Jurnal Pendidikan Dan Pembelajaran Dasar, 1(2).

Huda, M. (2014). Model-model Pengajaran dan Pembelajaran: Isu-isu Metodis dan Paradigmatis. Pustaka Pelajar.

Humaira, D., Fatmawati, F., \& Zulmiyetri, Z. (2012). Pelaksanaan Pembelajaran Bahasa Indonesia Bagi Anak Tunagrahita Ringan Kelas III di Slb Sabiluna Pariaman. Jurnal Penelitian Pendidikan Khusus, 1(3).

I Gusti Ayu Cahyani Ari Putri, Putra, KT.NGR. Semara, \& Zulaikha, S. (2014). Pengaruh Metode Pembelajaran SQ3R Terhadap Hasil Belajar Bahasa Indonesia Kelas V SD. Jurnal Mimbar PGSD Universitas Pendidikan Ganesha, 2(1).

Marantika, C. (2019). Pengaruh Buku Cerita Bergambar Terhadap Keterampilan Membaca Nyaring Peserta Didik Kelas III Min 7 Bandar Lampung (Doctoral Dissertation, Uin Raden Intan Lampung).

Masykur, Khanafiyah, S., \& Handayani, L. (2006). Penerapan Metode SQ3R Dalam Pembelajaran Kooperatif Untuk Meningkatkan Hasil Belajar Fisika Pokok Bahasan Tata Surya Pada Siswa Kelas VII SMP. Jurnal Pendidikan Fisika Indonesia, 4(2).

Mawaddah, E. N. (2018). Pengaruh Buku Cerita Bergambar Terhadap Kemampuan Membaca Pemahaman Siswa Kelas III MI Mimbarul Huda Langkap Tahun Pelajaran 2017/2018 (Doctoral Dissertation, Universitas Peradaban).

Mendikbud. (2019). Hasil PISA Indonesia 2018: Akses Makin Meluas, Saatnya Tingkatkan Kualitas. https://www.kemdikbud.go.id/main/blog/2019/12/hasil-pisa-indonesia-2018akses-makin-meluas-saatnya-tingkatkan-kualitas

Nurfitriana, E., \& Heryatun, Y. (2018). Pengaruh Pendekatan Contextual Teaching And Learning Berbantuan Media Buku Cerita Bergambar Terhadap Hasil Belajar Membaca 
Pemahaman Bahasa Indonesia. Primary: Jurnal Keilmuan Dan Kependidikan Dasar, 10(01), 43-50.

Nurhayati, S. (2018). Pengaruh Tehnik SQ3R (Survey, Question, Read, Recite, Review) Terhadap Keterampilan Membaca Pemahaman. Nuansa: Jurnal Penelitian Ilmu Sosial Dan Keagamaan Islam, 15(1).

Pramesti, U. D. (2015). Peningkatan Penguasaan Kosakata Bahasa Indonesia dalam Keterampilan Membaca Melalui Teka-Teki Silang (Penelitian tindakan di kelas VI SDN Surakarta 2, Kecamatan Suranenggala, Kabupaten Cirebon, Jawa Barat). Jurnal Puitika, 11(1).

Prayoga, R. W., Suwignyo, H., \& Harsiati, T. (2017). Peningkatan Keterampilan Menulis Cerita Narasi Melalui Penerapan Progam Literasi Berbantuan Media Buku Cerita Anak Pada Siswa SD. Jurnal Pendidikan: Teori, Penelitian, Dan Pengembangan, 2(11), $1498-1503$.

Putri, Y. E. (2019). Pengaruh Penggunaan Metode Pembelajaran SQ3R Terhadap Keterampilan Membaca Pemahaman di Sekolah Dasar. Jurnal Pendidikan Dan Pembelajaran, 8(3).

Rahmawati, A. (2016). Penerapan Sq3r Berbantuan Reka Cerita Gambar Untuk Meningkatkan Pemahaman Membaca dan Hasil Belajar Siswa. Profesi Pendidikan Dasar, 3(2).

Slamet, S. dan. (2014). Pembelajaran Keterampilan Berbahasa Indonesia Teori dan Aplikasi. Graha Ilmu.

Susanto, A. (2013). Teori Belajar dan Pembelajaran di Sekolah Dasar. Kencana Prenanda Media Grup. 